\title{
SUITABILITY OF ENTEC 26 AS A SOURCE OF NITROGEN FOR RED BEET AND CELERIAC
}

\author{
Eugeniusz KOŁOTA, Katarzyna ADAMCZEWSKA-SOWIŃSKA, Jan KRĘŻEL \\ Department of Horticulture \\ Wroclaw University of Environmental and Life Sciences \\ p. Grunwaldzki 24 a, 50-363 Wroclaw, Poland
}

Received: August 13, 2007; Accepted: September 17, 2007

\begin{abstract}
Summary
Entec 26 a new concept nitrogen fertilizer containing DMPP nitrification inhibitor was evaluated as a source of $\mathrm{N}$ for red beet and celeriac in field studies conducted in 2003-2006. In experiments with red beet there were determined the effects of the use of ammonium nitrate, ammonium sulphate, calcium nitrate and Entec 26 applied in the amounts of 50, 100, 150, $100+50 \mathrm{~kg} \mathrm{Nha}^{-1}$ in cul-

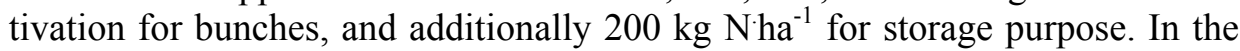
study with celeriac ammonium nitrate was supplied in split doses of 75,150 , 225 and $300 \mathrm{~kg} \mathrm{Nha}^{-1}$, while Entec 26 at the same rates as preplant or split application.

Results of the study showed that Entec 26 was equally valuable source of $\mathrm{N}$ for red beet as ammonium nitrate and calcium nitrate and more efficient than ammonium sulphate. In experiment with celeriac, plants supplied with this fertilizer in split doses overyielded those receiving ammonium nitrate in the same amounts. The important advantageous effect of Entec 26 use was a considerable reduction of nitrates accumulation in red beet grown for bunches and in celeriac roots.
\end{abstract}

key words: nitrogen fertilizers, red beet, celeriac, yield, plant composition

\section{INTRODUCTION}

A large part of success in vegetable culture has been due to proper mineral nutrition of vegetables. However, the surplus of supplied nutrients, especially nitrogen, may have an adverse effects on the environment as well as quality of the crops, and in consequence the health of human beings. In a temperate climatic zone usually not more than $50 \%$ of $\mathrm{N}$ applied is effectively used by plants, while considerable part is lost by leaching causing the contamination of ground and surface waters. On the other hand its intensive uptake by plants may result in high nitrates accumulation in the crop (Rahn 2002).

Corresponding author:

e-mail: kolota@ozi.ar.wroc.pl

(C) Copyright by RIVC 
These disadvantageous effects can be partly reduced by split application of $\mathrm{N}$ fertilizers as preplant and top dressing doses or the use of controlled release sources of the nutrient.

Considerable field research has been conducted with sulphur coated urea (Kołota 1982, Wiedenfeld 1986, Hochmuth 2003) and polymer coated urea (Drost et al. 2002) as nitrogen fertilizers for vegetables. High costs of production and similar or sometimes lower efficiency in comparison to soluble $\mathrm{N}$ sources were the reasons that till now such fertilizers are still not widely used in the field vegetable growing.

Another approach to reducing $\mathrm{N}$ losses in crop production is the use of nitrification inhibitors, which reduce the conversion of ammonium $\mathrm{N}$ to nitrate N. First studies with nitrification inhibitors were conducted with nitrapyrin (2chloro 6 trichloromethyl pyridine) and DCD (dicyandiamide), which have not received widespread commercial use in vegetable crops production (Hendrickson et al. 1978, Kołota \& Dobromilska 1985, Frye et al. 1989, Hochmuth 2003). Recently there was developed a new formula $\mathrm{N}$ fertilizer containing DMPP nitrification inhibitor. In a field studies there was proved its higher efficiency than soluble $\mathrm{N}$ sources expressed by either increased yield level or lower requirement for $\mathrm{N}$ rate application (Hähndel \& Strohm 2001, Hähndel \& Zerulla 2000, 2001, Pasda et al. 2001).

The aim of the experiment was to evaluate the effects of Entec 26 on yield and chemical composition of red beet and celeriac.

\section{MATERIAL AND METHODS}

Two field experiments with red beet and one with celeriac were conducted in 2003-2006 at Piastów Horticultural Experimental Station on a sandy clay soil with $\mathrm{pH}$ 7.1-7.4 and organic matter content 1.8\%. Available forms of phosphorus and potassium expressed in $1 \mathrm{dm}^{3}$ of the soil were raised up to the standard level for red beet (50 mg P, $150 \mathrm{mg} \mathrm{K}$ ) and celeriac ( $80 \mathrm{mg} \mathrm{P}, 200 \mathrm{mg} \mathrm{K}$ ) by early spring fertilization with triple superphosphate and potassium chloride.

In experiments I and II there were evaluated the effects of the use of ammonium nitrate, calcium nitrate, ammonium sulphate and Entec 26 - fertilizer containing the mixture of ammonium sulphate and ammonium nitrate with total amount of $26 \% \mathrm{~N}$ and addition of DMPP nitrification inhibitor $(3,4-$ dimethylpyrazole phosphate). All rested fertilizers were applied in the amounts of 50,100,150 and $100+50 \mathrm{~kg} \mathrm{Nha}{ }^{-1}$ in red beet grown for bunches and 50 , $100,150,100+50$ or $200 \mathrm{~kg} \mathrm{~N}^{-1} \mathrm{a}^{-1}$ in growing for storage purpose. Preplant doses of nitrogen were supplied shortly before seed sowing, while top dressing fertilization 4 weeks after sowing at the stage of 4-6 leaves. Seeds of Czerwona Kula cv. grown for bunches were sown into the field on 23 April in the rows 30 $\mathrm{cm}$ apart. Harvest was arranged in the half of July, when most of the plants formed roots $\geq 3.0 \mathrm{~cm}$ in diameter. For storage purpose seeds of the same cultivar were sown in the middle of June in the rows $45 \mathrm{~cm}$ apart, and harvest was done in early October. Marketable yield included roots with $4-10 \mathrm{~cm}$ in diameter. 
In experiment III with celeriac, ammonium nitrate was supplied in split doses of $75(1 / 2+1 / 2), 150(1 / 2+1 / 2), 225(1 / 3+1 / 3+1 / 3)$ and $300(1 / 2+1 / 4+1 / 4) \mathrm{kg}$ $\mathrm{N} \cdot \mathrm{ha}^{-1}$ in preplant and one or two top dressings, conducted on 8-9 June and 1516 July. Entec 26 was used in the same amounts of $\mathrm{N}$ and terms of fertilization as ammonium nitrate or in a single preplant dose incorporated into the soil by harrowing.

Celeriac cv. Monarch was grown from transplants produced in multicell trays, with cell volume $55.8 \mathrm{~cm}^{3}$, filled with peat substrate. Well developed and hardened seedlings were planted into the field on 6-9 May in spacing $40 \times 20$ $\mathrm{cm}$. During harvest there was evaluated the marketable yield of roots including those with $5-13 \mathrm{~cm}$ in diameter.

At harvest of red beet and celeriac, samples of edible parts were collected for nitrates determination by using the reflectometric method.

The experiments were arranged in two factorial design with four replications and plot area $8.1 \mathrm{~m}^{2}(2.7 \times 3 \mathrm{~m})$ for red beet and $7.2 \mathrm{~m}^{2}(2.4 \times 3 \mathrm{~m})$ for celeriac. Data of the study were analysed by standard statistical procedure and the least significant differences calculated by Tukey test at $\mathrm{P}=0.05$.

\section{RESULTS AND DISCUSSION}

Data of the study shown in Table 1 indicate that the marketable yield of red beet grown both for bunches and storage purpose was significantly influenced by the kind of nitrogen fertilizer as well as rate of this nutrient supplied to plants. Application of ammonium nitrate, calcium nitrate and Entec 26 gave similar to each other and considerable better results than ammonium sulphate. Irrespective of the $\mathrm{N}$ rate, the yield of plants supplied with ammonium sulphate was equal to 42.78 tha $^{-1}$ while on plots with the other sources of this nutrient varied between 48.00 and 50.69 tha $^{-1}$. Very similar response of this vegetable species was observed in its growing for roots used for storage purpose (Table 2).

The most efficient method of $\mathrm{N}$ plant nutrition, taking into account the growth rate of plants and yield of beet for bunches was split application of the total dose $150 \mathrm{~kg} \mathrm{Nha}{ }^{-1}$ and the use of $100 \mathrm{~kg} \mathrm{Nha}^{-1}$ before planting, supple-

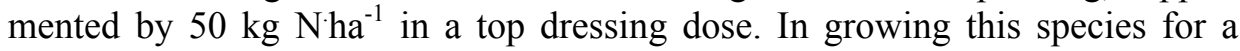
longer period of time to obtain the roots suitable for storage the best yielding was the treatment receiving $200 \mathrm{~kg} \mathrm{Nha}{ }^{-1}$ in one preplant fertilization rate. However, not significant differences were found between yield assured by this dose and $150 \mathrm{~kg} \mathrm{Nha}{ }^{-1}$. Split application of the nitrogen fertilization applied in the total amount of $150 \mathrm{~kg} \mathrm{Nha}^{-1}$ was more preferable for the table beet growth and yield only in the cultivation for bunches.

Nitrates accumulation, both in roots and leaves, increased along with the level of nitrogen supplied within 50 and $150 \mathrm{~kg} \mathrm{Nha}^{-1}$ from 121 to $487 \mathrm{mg} \mathrm{kg}^{-1}$ f.w. and from 798 to $1352 \mathrm{mg} \mathrm{kg}^{-1}$ f.w., respectively. In any treatment the accumulation of $\mathrm{NO}_{3}-\mathrm{N}$ did not reach the level of $1500 \mathrm{mg}$ per $1 \mathrm{~kg}$ of fresh weight, which is the acceptable limit for this vegetable species supplied to the market in Poland. 


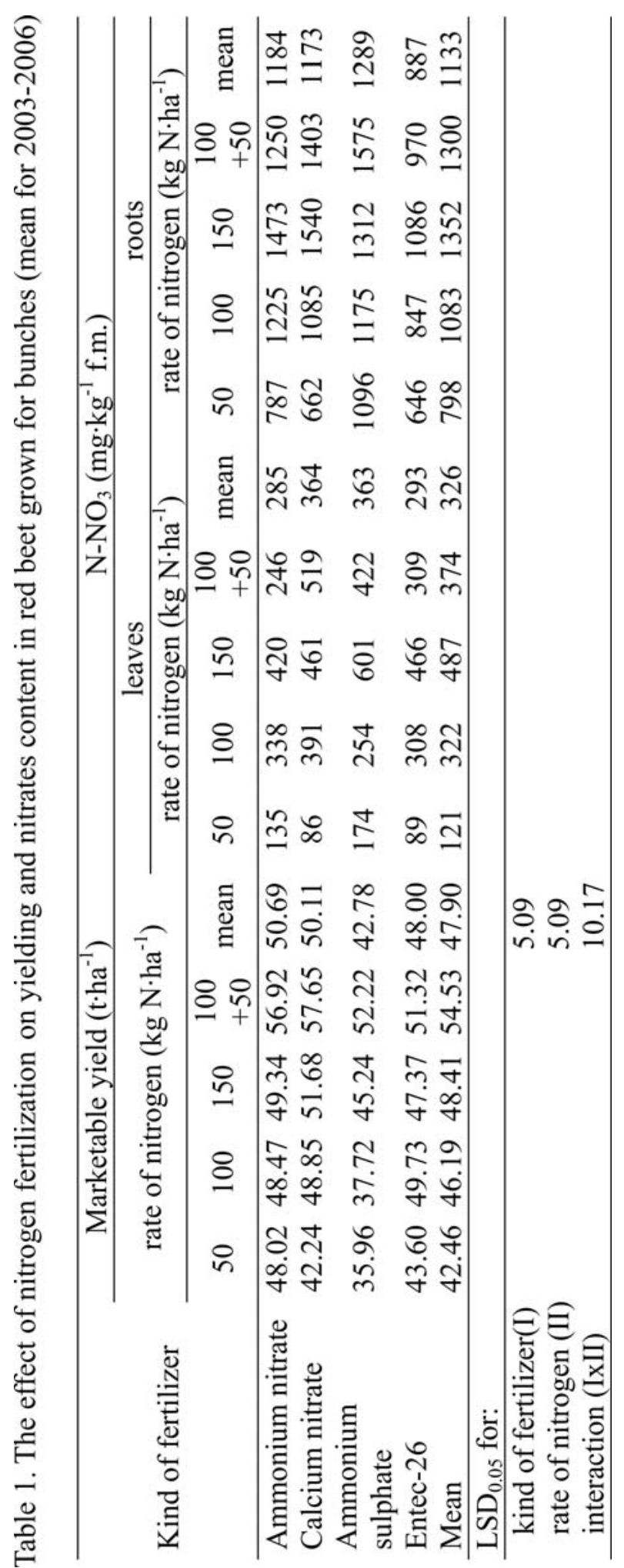


Table 2. The effect of nitrogen fertilization on yielding and nitrates content in red beet grown for storage (mean for 2003-2006)

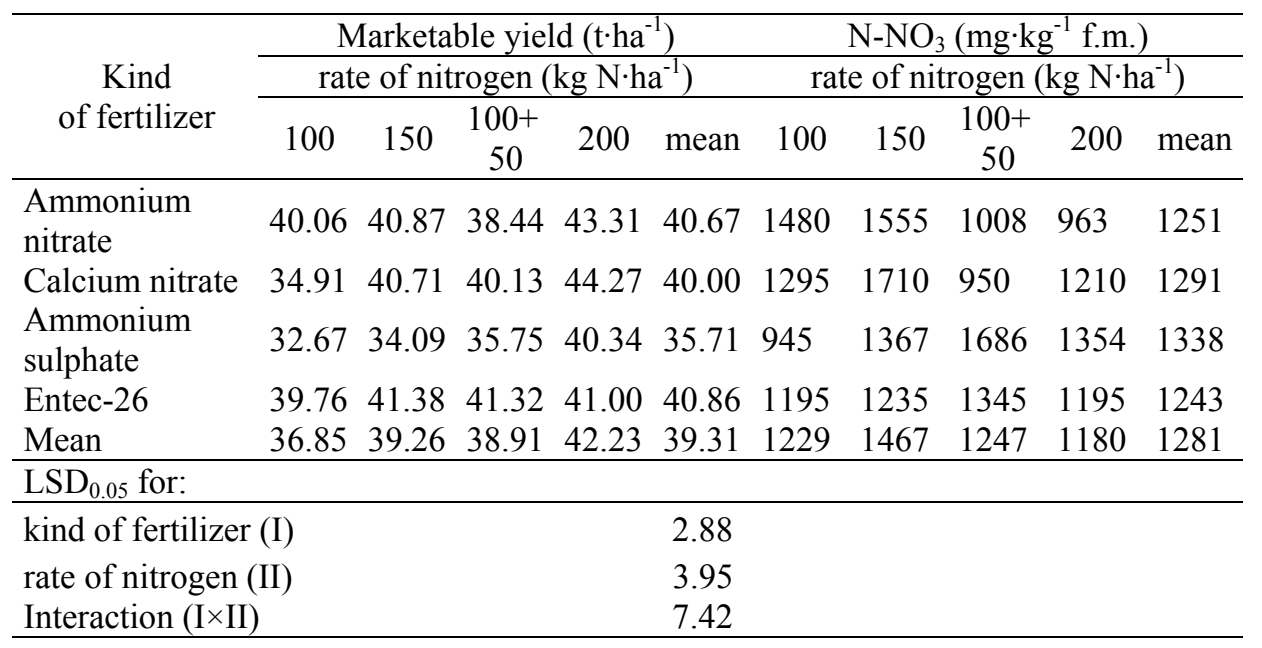

In reverse to the statement of Peck et al. (1974), split application of nitrogen fertilizers caused some reduction of $\mathrm{NO}_{3}-\mathrm{N}$ content in plants in comparison to the preplant dose. More efficient way for its limitation occurred in the case of Entec 26 use - a new concept nitrogen fertilizer containing DMPP as a nitrification inhibitor, which retards the conversion of ammonium $\mathrm{N}$ to nitrate $\mathrm{N}$ form. The positive effect of Entec 26 application was especially pronounced in roots of beets grown for bunches.

Data of the three year's study with celeriac showed that Entec 26 applied in a split dose (Table 3 ) was found to be a better source of nitrogen for this species than ammonium nitrate. The average marketable yield of roots for all tested $\mathrm{N}$ rates reached the level $47.04 \mathrm{tha}^{-1}$ in treatment with Entec 26, while 41.72 tha $\mathrm{a}^{-1}$ with ammonium nitrate. This advantageous effect was particularly noticeable at the doses of 75 and $150 \mathrm{~kg} \mathrm{Nha}{ }^{-1}$, which caused the yield increment by $16.2 \%$ and $26.7 \%$, respectively. Slight and not significant differences in efficiency of both fertilizers were observed in treatments supplied with 225 or 300 $\mathrm{kg} \mathrm{Nha}{ }^{-1}$ as well as in the case of application the whole amounts of $\mathrm{N}$ in one preplant dose.

Irrespective of the source of nitrogen and time of its application, the maximum yield of marketable celeriac roots was assured by using the dose of $225 \mathrm{~kg} \mathrm{Nha}{ }^{-1}$. This finding is generally in agreement with the recommendations elaborated by Krug (1991) and Sady (2000) for celeriac grown in not irrigated fields. 
Table 3. The effect of the kind of fertilizer and nitrogen rate on marketable yield and nitrates content in celeriac (mean for 2003-2005)

\begin{tabular}{|c|c|c|c|c|c|c|c|c|c|c|}
\hline \multirow{2}{*}{$\begin{array}{c}\text { Kind } \\
\text { of fertilizer }\end{array}$} & \multicolumn{5}{|c|}{$\begin{array}{c}\text { Marketable yield }\left(\mathrm{t} \cdot \mathrm{ha}^{-1}\right) \\
\text { rate of nitrogen }\left(\mathrm{kg} \mathrm{N} \cdot \mathrm{ha}^{-1}\right)\end{array}$} & \multicolumn{5}{|c|}{$\frac{\mathrm{N}-\mathrm{NO}_{3}\left(\mathrm{mg} \cdot \mathrm{kg}^{-1} \text { f.m. }\right)}{\text { rate of nitrogen }\left(\mathrm{kg} \mathrm{N} \cdot \mathrm{ha}^{-1}\right)}$} \\
\hline & 75 & 150 & 225 & 300 & mean & 75 & 150 & 225 & 300 & mean \\
\hline $\begin{array}{l}\text { Ammonium } \\
\text { nitrate } \\
\text { split application }\end{array}$ & 34.47 & 38.08 & 49.43 & 44.91 & 41.72 & 260 & 291 & 328 & 433 & 328 \\
\hline $\begin{array}{l}\text { Entec-26 } \\
\text { split application }\end{array}$ & 40.05 & 48.23 & 53.84 & 46.03 & 47.04 & 258 & 278 & 321 & 358 & 304 \\
\hline $\begin{array}{l}\text { Entec-26 } \\
\text { preplant appli- } \\
\text { cation }\end{array}$ & 36.47 & 40.47 & 53.09 & 38.55 & 42.15 & 239 & 265 & 272 & 306 & 271 \\
\hline Mean & 37.00 & 42.26 & 52.12 & 43.16 & 43.64 & 252 & 278 & 307 & 366 & 277 \\
\hline \multicolumn{11}{|l|}{$\mathrm{LSD}_{0.05}$ for: } \\
\hline \multicolumn{2}{|c|}{$\begin{array}{l}\text { kind of fertilizer (I) } \\
\text { rate of nitrogen (II) } \\
\text { interaction (I×II) }\end{array}$} & & & & $\begin{array}{l}4.14 \\
5.24 \\
\text { n.s. }\end{array}$ & & & & & \\
\hline
\end{tabular}

Chemical plant analysis indicated that the source of nitrogen considerably influenced nitrates accumulation in celeriac roots at harvest. Plants fertilized with Entec 26 contained lower amounts of $\mathrm{NO}_{3}-\mathrm{N}$ in comparison to those supplied with ammonium nitrate. Nitrates content in plants grown on plots fertilized with ammonium nitrate varied from $260 \mathrm{mg} \mathrm{kg}^{-1}$ f.w. at the dose of $75 \mathrm{~kg}$ $\mathrm{N} \cdot \mathrm{ha}^{-1}$ up to $433 \mathrm{mgkg}^{-1}$ f.w. at $300 \mathrm{~N}^{-1} \mathrm{ha}^{-1}$, exceeding the value admitted for this vegetable crop in Poland ( $400 \mathrm{mg} \mathrm{NO} 3-\mathrm{N}^{-1} \mathrm{~kg}^{-1}$ ). Split application of Entec 26 caused the decrease of $\mathrm{NO}_{3}-\mathrm{N}$ content to $258-358 \mathrm{mg} \mathrm{kg}^{-1}$ f.w. and its use in one preplant dose to $239-306 \mathrm{mg} \mathrm{kg}^{-1}$ f.w. depending on $\mathrm{N}$ dose. Beneficial effects of Entec 26 use as a source of nitrogen, expressed by the decrease of nitrates accumulation was observed in the other studies with celeriac and also another vegetable species such as lettuce, spinach, cauliflower, leek and carrot (Hähndel \& Zerulla 2001, Pasda et al. 2001).

Heavy $\mathrm{N}$ application at the rates of 225 and $300 \mathrm{~kg} \mathrm{Nha}^{-1}$ caused the increment of nitrogen uptake and nitrates accumulation in celeriac roots, irrespective of $\mathrm{N}$ source and method of its application.

\section{CONCLUSIONS}

1. Entec 26 was equally valuable source of nitrogen for red beet grown for bunches and storage purpose as ammonium nitrate and calcium nitrate, and provided higher yields of this vegetable species than ammonium sulphate.

2. Split application of Entec 26 produced higher, while preplant supply the whole fertilizer dose similar yield of celeriac roots as ammonium nitrate used at the same rates.

3. Plant nutrition with Entec 26 was associated with the reduction of nitrates accumulation in red beet grown for bunches and in celeriac roots. 
4. Maximum yield of red beet was assured by application $100 \mathrm{~kg} \mathrm{Nha}^{-1}$ as a

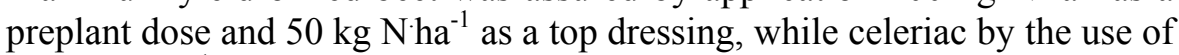
$225 \mathrm{~kg} \mathrm{Nha}^{-1}$ divided into there equal preplant and top dressing rates.

\section{REFERENCES}

Drost D., Koenig R., Tindall T. 2002. Nitrogen use efficiency and onion yield increased with a polymer-coated nitrogen source. HortScience 37(2): 338-342.

Frye W.W., Graets D.A., Locascio S.J., Reeves D.W., Touchton J.T. 1989. Dicyandiamide as a nitrification inhibitor in crop production in the southeastern USA. Commun. Soil Sci. Plant Anal. 20: 1969-1999.

Hähndel R., Strohm M. 2001. Neue stabilisierte N-Dünger : weitere Erfahrungen. Gemüse 6: 13-16. [in German]

Hähndel R., Zerulla W. 2000. Wirkung auf Ertrag und Qualität von Gemüse bei Entec Düngung. Gemüse 3: 14-16. [in German]

Hähndel R., Zerulla W. 2001. Effects of ammonium-stabilized N-fertilizers on yield and quality of vegetables. Acta Hort. 563: 81-86.

Hendrickson L.L., Keeney D.R., Walsh L.M., Liegel E.A. 1978. Evaluation of nitrapyrin as a means of improving N efficiency in irrigated sands. Agron. J. 70: 699-703.

Hochmuth G.J. 2003. Progress in mineral nutrition and nutrient management for vegetable crops in the last 25 years. HortScience 38(5): 999-1003.

Kołota E. 1982. [Nitrogen fertilization influence on yields and irrigation efficiency of white cabbage and leeks.] Rocz. Nauk Rol. Seria A 105 (3): 161-175. [in Polish with English summary]

Kołota E., Dobromilska R. 1985. [Effect of nitrogen form and dose and of nitrification inhibitor addition on yield and quality of radish.] Biul. Warz. 28: 95-112. [in Polish with English summary]

Krug H. 1991. Gemüseproduktion. Ein Lehr- und Nachschlagewerk für Studium und Praxis. 2 Auflage. Paul Parey. Berlin und Hamburg. [in German]

Pasda G., Hähndel R., Zerulla W. 2001. Effect of fertilizer with the new nitrification inhibitor DMPP (3,4-dimethylpyrazole phosphate) on yield and quality of agricultural and horticultural crops. Biology and Fertility of Soils 34(2): 85-97.

Peck N.H., Cantliffe D.J., Shallenberger R.S., Bourke J.B. 1974. Table beet (Beta vulgaris L.) and nitrogen. Search. Agriculture 4(6): 1-25.

Rahn C.R. 2002. Management strategies to reduce nutrient losses from vegetable crops. Acta Hort. 571:19-29.

Sady W. 2000. Nawożenie warzyw polowych. Plantpress. Kraków. [in Polish]

Wiedenfeld R.P. 1986. Rate, timing and slow release nitrogen fertilizers on cabbage and onion. HortScience 21: 236-238.

\section{PRZYDATNOŚĆ NAWOZU ENTEC 26 W UPRAWIE BURAKA ĆWIKŁOWEGO I SELERA KORZENIOWEGO}

\section{Streszczenie}

W 3 doświadczeniach polowych przeprowadzonych w latach 2003-2006 oceniono przydatność nawozu Entec 26 zawierającego DMPP (2-chloro-6-trójchlorometylopirydyna) jako inhibitor nitryfikacji do nawożenia buraka ćwikłowego i selera korzeniowego. $\mathrm{W}$ doświadczeniach $\mathrm{z}$ burakiem przedmiotem oceny były saletra amonowa, saletra wapniowa, siarczan amonu i Entec 26 stosowane w dawkach 50, 100, 150 i 100 
+ $50 \mathrm{~kg} \mathrm{~N} \cdot \mathrm{ha}^{-1} \mathrm{w}$ uprawie na zbiór pęczkowy oraz dodatkowo $200 \mathrm{~kg} \mathrm{~N} \cdot \mathrm{ha}^{-1}$ na potrzeby przechowalnictwa. Seler nawożono podzielonymi dawkami saletry amonowej wynoszącymi 75, 150, 225 i $300 \mathrm{~kg} \mathrm{~N}^{-1} \mathrm{ha}^{-1}$ oraz tej samej wielkości dawkami nawozu Entec 26 stosowanymi w całości przedwegetacyjnie bądź w nawożeniu dzielonym.

Wyniki przeprowadzonych badań dowiodły, że Entec 26 stanowił równorzędne źródło azotu dla buraka ćwikłowego jak saletra amonowa i saletra wapniowa, przewyższał natomiast pod względem skuteczności siarczan amonu. W uprawie selera użycie dawki podzielonej tego nawozu zapewniło uzyskanie wyższego plonu handlowego korzeni aniżeli równorzędne dawki saletry amonowej. Istotną korzyścią wynikającą ze stosowania nawozu Entec 26 było obniżenie zawartości azotanów w buraku ćwikłowym zbieranym na pęczki oraz w korzeniach spichrzowych selera. 